\title{
Planted Sludge Drying Beds in Treatment of Faecal Sludge from Ouagadougou: Case of Two Local Plant Species
}

\author{
Sawadogo Bienvenue Joceline ${ }^{1}$, Martine Koné ${ }^{2 *}$, Ouattara Yacouba ${ }^{2}$, Yonli H. Arsène ${ }^{1}$ \\ ${ }^{1}$ UFR/SEA, Université de Ouagadougou, Ouagadougou, Burkina Faso \\ ${ }^{2}$ Institut de Recherche en Sciences Appliquées et Technologies/CNRST, Ouagadougou, Burkina Faso \\ Email: *koneba2003@yahoo.fr
}

Received 1 May 2016; accepted 11 June 2016; published 14 June 2016

Copyright (C) 2016 by authors and Scientific Research Publishing Inc.

This work is licensed under the Creative Commons Attribution International License (CC BY).

http://creativecommons.org/licenses/by/4.0/

c) (i) Open Access

\begin{abstract}
Management of wastewater is a concern of developing countries. In Burkina Faso, an on-site septic system installed on the property is predominant and those systems product high quantities of faecal sludge which are not treated adequately before discharge. Our country is mainly fed by surface water, while water is the main vector of many diseases. So it is very important to manage efficiently wastewater and faeces. The treatment of faecal sludge by planted beds can use local persistent emergent plants like Andropogon gayanus (LPA) and Cymbopogon nardus (LPN). Those planted beds are compared to a non-planted bed (sludge drying bed) (LT). Treating raw sludge (BB) we got the yield over $90 \%$ concerning the biological oxygen demand $\left(B^{\circ} D_{5}\right)$ for the LPA while the two others gave performances of $75 \%$ and $76 \%$ respectively. Regarding the chemical oxygen demand (COD), LPN gave better yields with $77 \%$ of removal against $71 \%$ and $69 \%$ for LPA and LT respectively. Overall, the pilots assured removal of orthophosphates varying between $77 \%$ and $79 \%$, while the Kjeldahl nitrogen is removed by the various beds with respective fields of $94 \%$, $96.5 \%$ and $97.5 \%$ for LPN, LPA and LT. The microbiological pollution abatement is in the order of $1 \mathrm{log}$ unit on average for all beds.
\end{abstract}

\section{Keywords}

Sludge Drying Bed, Andropogon gayanus, Cymbopogon nardus, Planted Beds, $\mathrm{BOD}_{5}$

\section{Introduction}

In the developing countries in general and the sub-Saharan countries in particular, autonomous sanitation systems "Corresponding author.

How to cite this paper: Joceline, S.B., Koné, M., Yacouba, O. and Arsène, Y.H. (2016) Planted Sludge Drying Beds in Treatment of Faecal Sludge from Ouagadougou: Case of Two Local Plant Species. Journal of Water Resource and Protection, 8, 697-705. http://dx.doi.org/10.4236/jwarp.2016.87057 
are predominate [1]. They cover more than $80 \%$ of homes that have a sewerage system in major cities [2].

In Bamako, 98\% of the population uses latrines and septic tanks [3], while in Burkina Faso, it reaches 71.9\% in urban areas [4]. In this context, increasing urbanization in developing countries requires the consideration of household waste such as wastewater and sludge coming from autonomous sanitation system, because of health and environmental risk [5].

In Burkina Faso, the major part of the wastewater and sludge is discharged into nature (drains, fields, bushes or outskirts of the city) without treatment. It is therefore urgent to take appropriate measures to control faecal peril by finding treatment and management systems.

This study aims to contribute to the production of scientific data in the field of treatment of faecal sludge by planted beds with local plants in order to identify which one offers the best potential in terms of sludge dewatering and reduce pollution efficiently in our climate context.

\section{Materials and Methods}

\subsection{Organic Material}

The sludge treated by planted drying beds, come from households' septic system or septic tanks (Figure 1). So, the sludge used during this study was got by mechanic drain, stored on site in deep pit under anaerobic conditions in order to keep the same characteristic of sludge.

Scientific classification of Andropogon gayanus: kingdom: plantae; Class: grasses; Family: Poaceae; Genus: Andropogon; Species: gayanus.

This herb, very appreciated by domestic ruminants in tropical areas is perennial tufted, erect and robust. It has a strong root system (highly developed); its roots can reach $3 \mathrm{~m}$ deep (Figure 2).
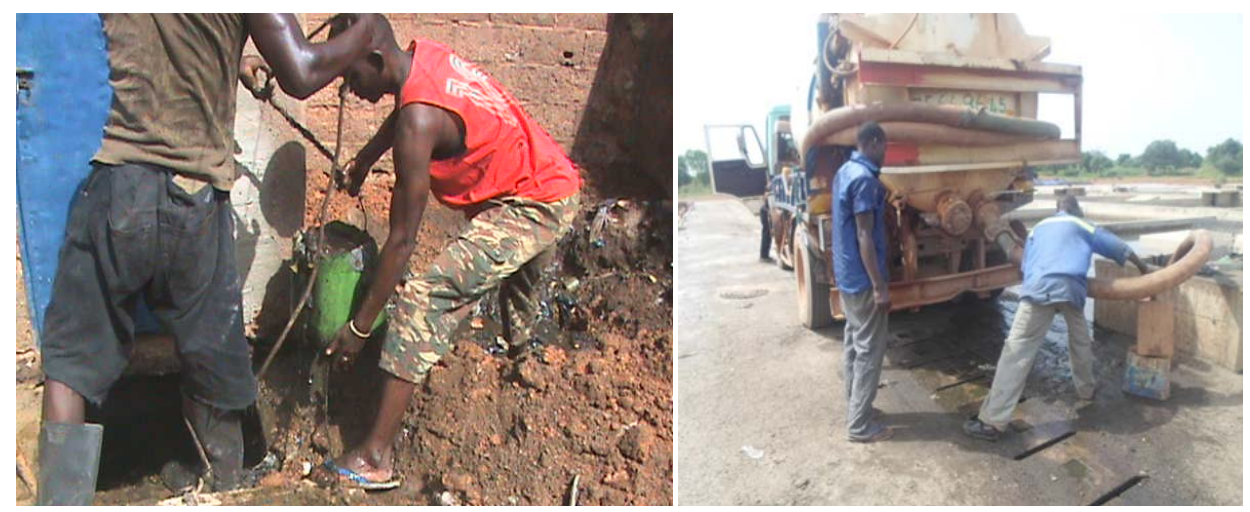

Figure 1. Manual drain and mechanical drain.

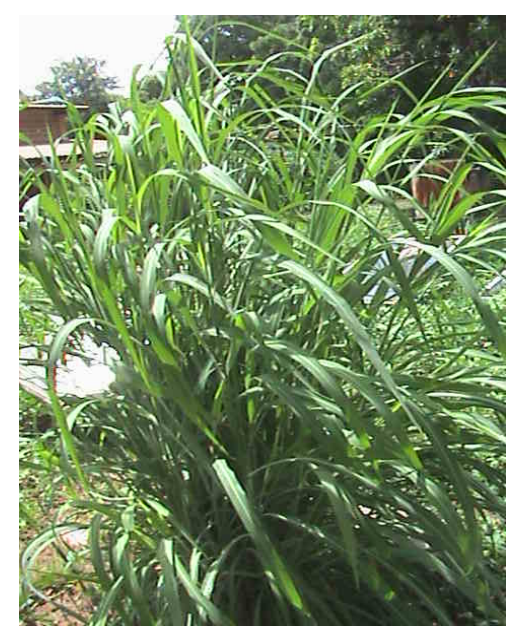

Figure 2. Andropogon gayanus. 
Botanical description of Cymbopogon nardus: kingdom: plantae; Class: grasses; Family: Poaceae; Genus: Cymbopogon; Species: nardus.

Cymbopogon nardus is named citronella grass; it is a perennial of poaceae grass family, originating in tropical Asia (Figure 3).

These two plants were selected for the following reasons:

These are local plants, easy to find in our regions and they like wetlands conditions.

They are perennials that exist throughout the year and that are resistant to floods, drought and fires.

Their root system is well developed, allowing for ventilation of the gravel so a good percolation of leachate.

They have a very high power of evapotranspiration, so a great power of sludge dewatering.

\subsection{Methods}

\subsubsection{Conception of Planted and Non-Planted Sludge Drying Beds}

To build the beds we used bricks with following dimensions $20 \times 15 \times 10 \mathrm{~cm}^{3}$.

By bed, two tubes (in polyvinyl chloride) which will ensure the beds ventilation were installed.

We filled the beds with the layers of the following materials: coarse gravel $(20 \mathrm{~cm})$, fine gravel $(30 \mathrm{~cm})$, and finally sand $(30 \mathrm{~cm})$ bottom up.

Three juxtaposed beds (Figure 4) were built separated by smooth partitions to avoid seepage.

Each sludge drying bed (planted or unplanted) has a surface of $1 \mathrm{~m}^{2}$. The bottom of the beds is inclined to $10^{\circ}$ to allow a flow of leachate oriented toward an outlet. At the output of each bed is placed a PVC pipe to drain water which is then collected in containers.

At the two corners to the back of each bed are placed PVC pipes with laterally perforated small holes to allow better aeration of the filter systems.

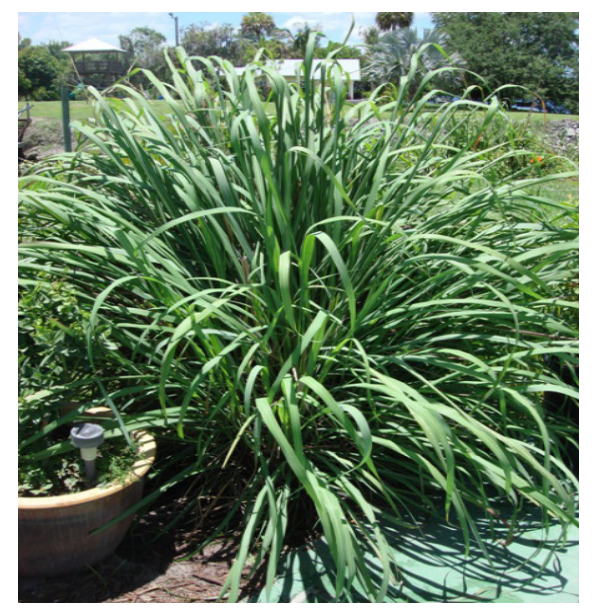

Figure 3. Cymbopogon nardus.

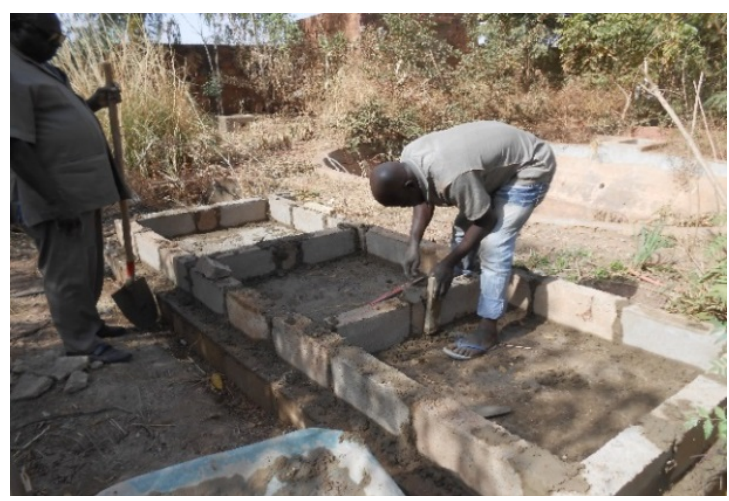

Figure 4. The construction of pilots. 
The beds were watered daily for a week to fully wash the mass and remove the maximum amount of impurities, before transplanting seedlings. These plants were harvested in our research center (Figure 2 and Figure 3 ) and transplanted into two pilots, with 5 plants per bed $\left(5\right.$ plants $\left./ \mathrm{m}^{2}\right)$. The first bed was planted with Andropogon gayanus, the second with Cymbopogon nardus and the last one, non planted serves as a control. The three beds were fed with faecal sludge for several weeks to allow development of the plants and to ensure the presence of a root system before levies. That also allows the formation of a biofilm on materials which will ensure the biological treatment of faecal sludge (Figure 5).

\subsubsection{Loading of Pilots with Faecal Sludge}

The beds were fed firstly two successive days followed by three days of rest. This pace was unsuitable because of too long rest period with a pronounced wilting for plants. Two days of feeding followed by two days of rest was adopted. The rest time is essential because it allows the filter to recharge oxygen but also prevents clogging of the system [6].

\subsubsection{Sampling and Analyzes}

In situ analyzes

$\mathrm{pH}$ : the negative logarithm of the concentration of $\mathrm{H}^{+}$: $\mathrm{pH}=-\log \left[\mathrm{H}^{+}\right]$.

The $\mathrm{pH}$ determines the acidity or alkalinity of the environment; it has a great influence on the development of microorganisms and the biochemical degradation process.

Electrical conductivity: It measures the mineralization of a solution. If the mineralization is increasing the conductivity increases. It is expressed in $\mathrm{mS} / \mathrm{cm}$ (milli Siemens per $\mathrm{cm}$ ).

Dissolved oxygen: it represents the amount of oxygen present in dissolved form in the sample available to allow oxidation of the organic material by microorganisms.

\subsubsection{Laboratory Analyzes}

In the laboratory the physical and chemical parameters $\left(\mathrm{BOD}_{5}, \mathrm{COD}\right.$, nitrates, nitrites, Kjeldahl nitrogen and phosphorus and bacteriological pollutants were analyzed.

COD: It expresses the amount of oxygen required to degrade chemically, the organic and inorganic materials present in the faecal sludge. It is determined after chemical oxidation in strong sulfuric acid medium by an excess of potassium dichromate $\left(\mathrm{K}_{2} \mathrm{Cr}_{2} \mathrm{O}_{7}\right)$ for two hours at the temperature of $148^{\circ} \mathrm{C}-150^{\circ} \mathrm{C}$. The reading was made with a spectrophotometer HACH DR 2400.

Phosphorus comes from the human metabolism and cleaning products. However, it can come from natural sources like rock. The measurement was made using the photometric method.

Kjeldahl Nitrogen: This is oxidizable nitrogen consisting of ammonia nitrogen and organic nitrogen. The nitrogen is mineralized to $150^{\circ} \mathrm{C}$ in nitrates, which are then determined by spectrophotometry, with the Palintest spectrophotometer DR 7000.

The nitrates and nitrites: They are the oxidized mineral forms of nitrogen. The measurement was made using the photometric method and the reading was made on the spectrophotometer DR 7000.

Ammonium is also a mineralized form of nitrogen that is produced when the medium is anaerobic (reducing conditions). It is measured spectrophotometrically.

\subsubsection{The Thermotolerant Coliforms}

The presence of faecal coliforms gives indications about the efficiency of the treatment. Their presence is a sign of a recent faecal pollution, and means the presence of other pathogens. The analysis was performed by using a culture medium and incubation in a Memmert incubator at $44^{\circ} \mathrm{C}$ for 48 hours.

The data processing was done on Excel.

\section{Results and Discussion}

\subsection{Evolution of Physical and Chemical Parameters}

The following table shows the results of different physicochemical parameters analyzed in this study.

According to the results obtained from the different analyzes (Table 1), except $\mathrm{pH}$, we notice a strong variation of values for the different parameters between raw sludge (BB) and the different beds. 


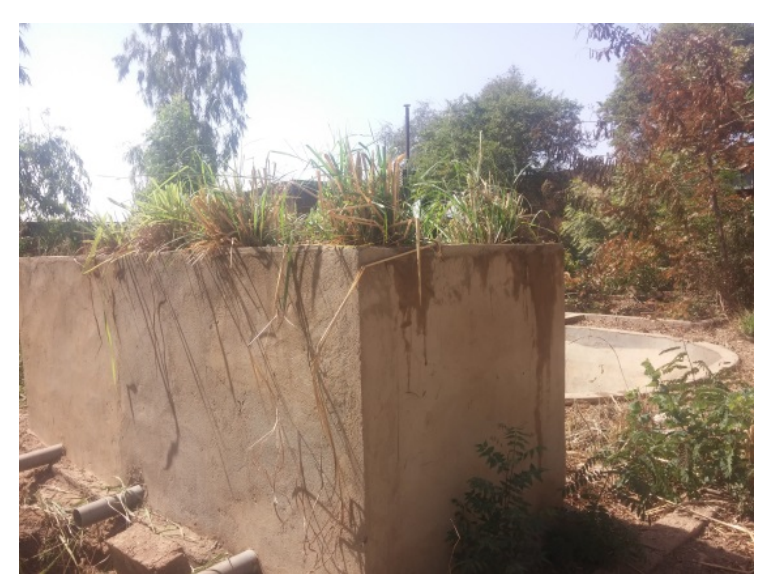

Figure 5. Pilots during operation.

Table 1. The average values of various parameters.

\begin{tabular}{ccccccccc}
\hline & $\mathrm{pH}$ & $\begin{array}{c}\mathrm{EC} \\
(\mathrm{mS} / \mathrm{cm})\end{array}$ & $\begin{array}{c}\text { Disolved oxygen } \\
(\mathrm{mg} / \mathrm{L})\end{array}$ & $\begin{array}{c}\mathrm{COD} \\
(\mathrm{mg} / \mathrm{L})\end{array}$ & $\begin{array}{c}\mathrm{BOD} \mathrm{D}_{5} \\
(\mathrm{mg} / \mathrm{L})\end{array}$ & $\begin{array}{c}\mathrm{PO}_{4} \\
(\mathrm{mg} / \mathrm{L})\end{array}$ & $\begin{array}{c}\text { Nitrates } \\
(\mathrm{mg} / \mathrm{L})\end{array}$ & $\begin{array}{c}\text { Kjeldahl Nitrogen } \\
(\mathrm{mg} / \mathrm{L})\end{array}$ \\
\hline Raw sludge & 8.03 & 3.32 & 0.81 & 952 & 441 & 98 & 23 & 739 \\
LPA & 7.74 & 3.23 & 2.92 & 324 & 89 & 36 & 196 \\
LPN & 7.70 & 2.93 & 3.08 & 283 & 63 & 25 & 252 & 21 \\
LT & 7.56 & 2.83 & 2.81 & 355 & 82 & 23 & 290 & 11 \\
\hline
\end{tabular}

\subsection{1. $\mathrm{pH}$}

With the value of 8.03 , the raw sludge is alkaline, due to their anaerobic condition.

However, the $\mathrm{pH}$ decreases in the leachate of the different beds, although they remain slightly alkaline. In fact, the bacteria grow in general at $\mathrm{pH}$ between 5 and 9. Those who provide nitrification such as Nitrosomonas have their best growth in an alkaline environment with a $\mathrm{pH}$ between 7.4 and 9 .

\subsubsection{Electrical Conductivity}

The conductivity is relatively high in the raw sludge with an average value of $3.23 \mathrm{mS} / \mathrm{cm}$ in comparison with the results obtained with the various pilots.

Indeed, the conductivity decreases with treatment for all three pilots with respective averages of $2.83 \mathrm{mS} / \mathrm{cm}$, $2.93 \mathrm{mS} / \mathrm{cm}$ and $3.23 \mathrm{mS} / \mathrm{cm}$ for the non-planted drying bed (LT), drying bed planted with Nardus (LPN) and drying bed planted with Andropogon (LPA). The strong mineralization of filtrates of planted drying beds compared to non-planted bed could be explained by the presence of the root system that favors infiltration but also by the bacteria activity in greater number in the planted beds. The root biomass creates an area favorable to the growth of purifying bacteria which mineralize organic matter, while the conditions of hydraulic operation are improved by the presence of the roots [4].

The two planted drying beds showed different performance, suggesting a different development of their root systems; the root system is more developed concerning Andropogon gayanus; this allows a good mineralization of the mud and gives the highest conductivity values concerning the three beds.

However it is important to note that Faecal sludge is subject to high variations due to the storage conditions like duration, temperature, intrusion of groundwater in septic tanks, performance of septic tanks, and tank emptying technology used [2].

So the conductivity of sludge can depend on those parameters. Allandiguibaye observed the conductivities of $6.52 \mathrm{mS} / \mathrm{cm}$ and $5.82 \mathrm{mS} / \mathrm{cm}$ after sand filtration of sludge coming from traditional latrine and those of septic tank respectively [7]. Regarding sludge from septic he obtained similar values to the results of this study.

\subsubsection{Dissolved Oxygen}

Regarding dissolved oxygen, it remains higher in the percolates $(2.5$ to $3.94 \mathrm{mg} / \mathrm{L})$ relative to the raw sludge 
(0.22 to $1.22 \mathrm{mg} / \mathrm{L})$.

All three pilots have similar behavior, because of the same materials of filtration. Indeed, aeration is mainly by convection and also through ventilation systems installed in the back of the pilots. The process is aerobic, and the plant roots were not well developed to allow them to impact the aeration processes. So the leachates are found in all the three pilots in similar oxygenation condition.

\subsection{Removal of Organic Pollution}

\section{Organic Pollution (BOD 5 , COD) after Treatment by the Pilots}

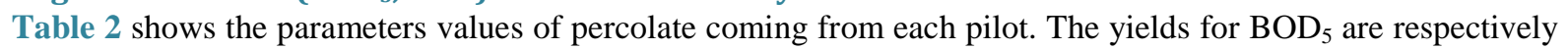
90\%, 75\% and 76\% for LPA, LPN and LT. These values are lower compared to those obtained by Barro who used Echinochloa piramidalis [8]. The diversity of plant species and their specific properties could justify the difference in their ability to eliminate pollution.

Moreover, according to the season (sunny season, dry season or rainy season), the planted drying beds do not give the same performance. The origin and nature of the sludge also affect the results dramatically.

According our results (Table 2), the drying bed planted with Andropogon gayanus (LPA) best removes BOD $_{5}$ compared to the other two pilots. This fact is corroborated by the results of Koné who noted that this plant absorbs a lot of water through evapotranspiration, so could easily and quickly dewatered sludge [4]. However, its performance remains below our expectations, due certainly to Youth of plants that had only 5 months of existence (February to June 2015); so, we think that after a long time of growth, with more development of the roots, the results could be improved.

As against, the COD yields are respectively 68.89\%, 76.55\%, and 71.45\% for LPA, LPN and LT. LPN gives better performance than LPA. This could be explained by the more easy infiltration through the bed planted by Andropogon due to development of his roots compared with the other planted bed. Indeed, it's known that, Andropogon gayanus has long and dense root system compared to Cymbopogon nardus, this contribute to the good infiltration.

In other words, the bed planted with Cymbopogon nardus eliminates slowly but betters the COD.

\subsection{Removal of Nutriments}

\subsubsection{Phosphorus Evolution}

Phosphorus exists in the water in either in a dissolved form or in a particulate form. The dissolved form of inorganic phosphate (orthophosphate) is the form required the plants growth. In excess, orthophosphates and nitrates cause eutrophication.

Figure 6 gives the concentrations of the orthophosphates in raw sludge and those contained in each filtrate coming from the pilots. The raw sludge has highly concentrated of orthophosphate with an average concentration of $97.6 \mathrm{mg} / \mathrm{L}$.

After the treatment, the contents of orthophosphate are respectively $23 \mathrm{mg} / \mathrm{L}, 22.6 \mathrm{mg} / \mathrm{L}$ and $20 \mathrm{mg} / \mathrm{L}$ for the filtrates from LPA, LT and LPN. The orthophosphates are eliminated primarily by adsorption on the granular medium. If the removal efficiencies of orthophosphate varying between $77 \%$ and $79 \%$ appear to be satisfactory for the various pilots, it should be noted that other authors got higher yields, reaching 94.27\%, particularly at the beginning of biological reactor operation [6]. However, these authors found that in time, the orthophosphate concentration increases because of the risk of release of adsorbed ions, which is due to the saturation of the adsorption sites.

By comparing the performance of different drivers, LPN gave the best performance concerning orthophosphates retention, while LPA and LT, presented identical performance. A portion of the orthophosphate is removed by the plants for their growth. Bacteria also are involved in the mineralization and removal of phosphorus, while sludge deposed on bed still contains a part of phosphorus. The values obtained in this experience are similar to those obtained by other studies such as which was related by Abiola in Senegal with Echinochloa pyramidalis species that show a high retention of orthophosphate in part by the solid filtering mass and secondly by plant uptake [9].

\subsubsection{Evolution Nitrogen Contents}

Kjeldahl nitrogen is the combination of organically bound nitrogen and ammonia in wastewater.

The values of Kjeldahl nitrogen (KN) obtained for each pilot relative to the raw sludge are shown through 
Table 2. Removal efficiences.

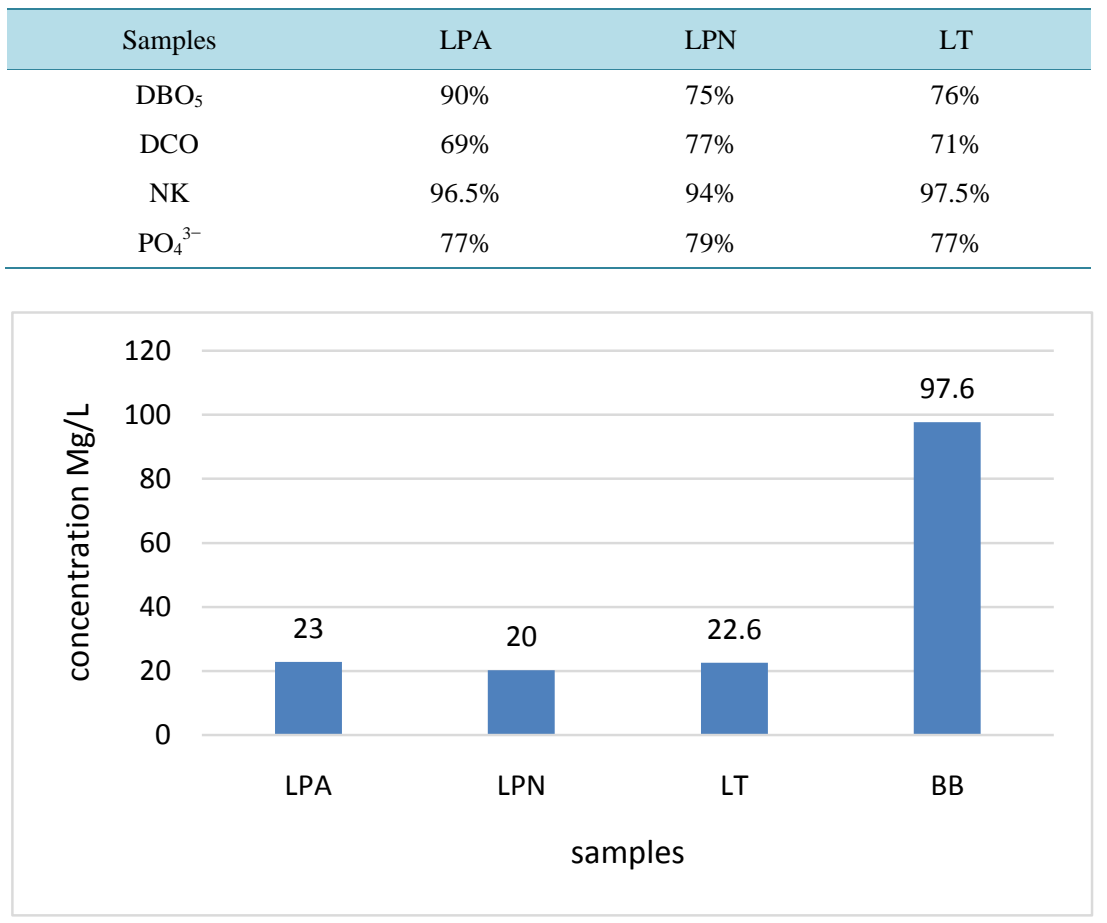

Figure 6. Evolution of orthophosphate contents for different pilots.

Figure 7. The KN is nitrogen which can be oxidized. It is the sum of organic nitrogen and ammonia nitrogen; the results obtained indicate an average of $439 \mathrm{mg} / \mathrm{L}$ in the raw sludge. The mineralization of sludge has actually started since the septic tank with the formation of ammonia nitrogen that is why we noted ammonia average of $235 \mathrm{mg} / \mathrm{L}$. Conversely the nitrates are in very small quantities in the raw sludge.

After treatment it results a good elimination of Kjeldahl nitrogen (Figure 7), by a good oxidation conditions in the three pilots. This fact is confirmed by Figure 8 which indicates the presence of nitrates in the filtrate with the average concentrations of $290 \mathrm{mg} / \mathrm{L}, 252 \mathrm{mg} / \mathrm{L}$ and $196 \mathrm{mg} / \mathrm{L}$ respectively for LT, LPN and LPA. Indeed, aerobic operating conditions in the pilots promote the oxidation of nitrogen. In addition to the nitrate, we noted the presence of nitrites in significant levels in the three pilots, denoting well as oxidizing conditions could be improved with the presence of more ventilation shafts.

Despite this fact and taking into account the average performance of the pilots in terms of nitrification the non-planted drying bed ensures a good level of nitrification. However, that should not overshadow the levies of nitrates by plants for their growth, given that nitrates as orthophosphates are nutrients for plants. This hypothesis suggests a slightly greater nutrient uptake by Andropogon gayanus compared to Cymbopogon nardus.

Nevertheless, the performance of our planted drying beds are still below those obtained in France by Lienard et al. with the species Phragmites australis [10]. This can confirm that the processing performance depends to plant species used but to probably also their development stage.

In sum, the good removal of KN and the high presence of oxidized forms of nitrogen mean a good mineralization of the Kjeldahl nitrogen in general.

The results obtained show very high levels of ammonium $(350 \mathrm{mg} / \mathrm{L})$ in raw sludge. This is normal because in the septic tank, the degradation process is anaerobic, with converting organic nitrogen to ammonia nitrogen. We conducted analyzes of other samples of sludge, in order to compare their ammonium content to ours and the results indicate very high levels also. Moreover, these results are similar to those obtained by Kengne in Cameroon with Echinochloa pyramidalis and Cyperus papyrus [11].

\subsection{Elimination of Microbiological Pollution}

The sludge retention time in the septic tank (4 - 6 years) and depot on the test site have caused a reduction on 


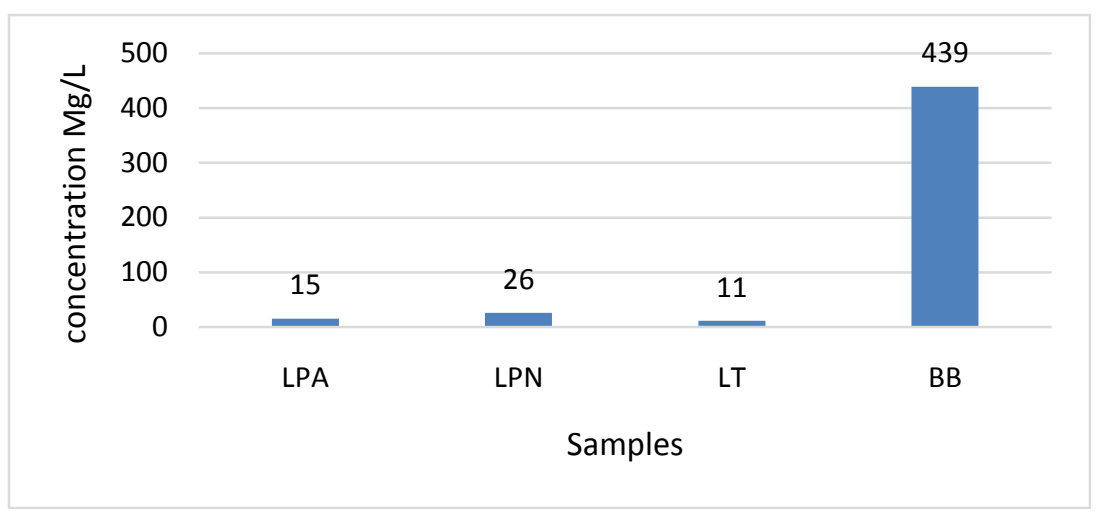

Figure 7. Kjeldahl nitrogen contents for different beds and raw sludge.

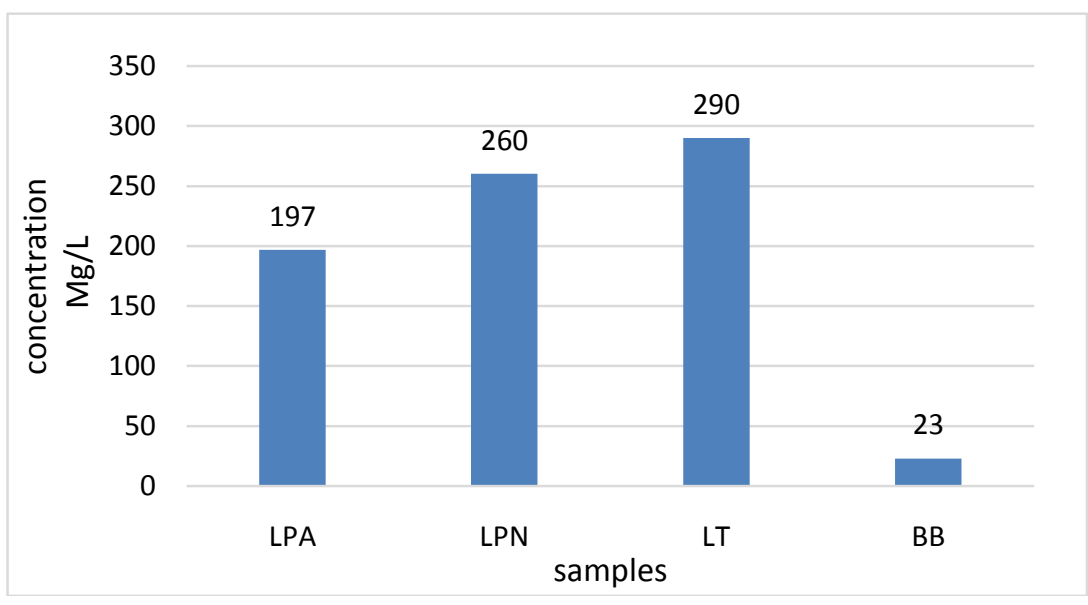

Figure 8. Nitrate levels for different beds and the raw sludge.

this parameter whose values seem weak. This context has impacted the concentration of faecal coliform, a treatment efficiency indicator. Indeed, concentrations in sludge are generally higher than what we found in this study (Table 3); Allandiguibaye has indicated the levels of $0.75 \times 105 \mathrm{CFU} / 100 \mathrm{~mL}$ with sludge from septic tank [7], while Mbéguéré and et al. report 3.6 × 108 CFU/100 mL [1].

In terms of comparison of pilot performance, based on the collected filtrate, Table 3 shows that the treatment has a minor impact on the average levels of faecal coliforms at each pilot compared to the raw sludge. These values are respectively for LPA, LPN and LT: $5.2 \times 102 \mathrm{CFU} / 100 \mathrm{ml} ; 7.8 \times 102 \mathrm{CFU} / 100 \mathrm{ml} ; 9.2 \times 102$ $\mathrm{CFU} / 100 \mathrm{~mL}$. These average content of CF in raw sludge, correspond to the reductions in order of $1 \mathrm{ulog}$. Our results corroborate those of Mbéguéré and et al. [1], who got in Dakar for 3 experimental pilots with loads between 20 and $40 \mathrm{~cm} / \mathrm{m}^{2}$, a removal of faecal coliform reaching 1.25 to 1.46 ulog and a yield of $100 \%$ of helminth eggs removal.

In sum, the results indicate some level of pathogen removal by planted beds that demonstrate the effectiveness of this technology to treat faecal sludge, since LPA eliminates 90\%, 86\% and LPN LPT 83\% of faecal coliforms. These results could know improvements in a context of very sunny weather which favors the elimination of pathogens. Andropogon gayanus is therefore in this case the plant best suited to ensure proper elimination of pathogens.

\section{Conclusions}

The treatment of faecal sludge by planted bed with Andropogon gayanus gave good results with a yield of 90\% concerning $\mathrm{DBO}_{5}$, while Cymbopogon nardus and unplanted bed gave similar performance $75 \% 76 \%$. As for the chemical oxygen demand, the abatement rates remain relatively low in the three pilot $69 \%$ (LPA) $77 \%$ (LPN) and $71 \%$ (LT). The yields of orthophosphate removal of 77\%, 77\% and 79\% respectively for LT, LPA and LPN 
Table 3. Results of microbiological analyzes of samples.

\begin{tabular}{ccccc}
\hline Samples & LPA & LPN & LT & BB \\
\hline Faecal Coliform (UFC/100 ml) & $5.2 \times 10^{2,}$ & $7.8 \times 10^{2}$ & $9.2 \times 10^{2}$ & $5.4 \times 10^{3}$ \\
\hline
\end{tabular}

indicate a greater retention by the non-planted bed. The removal of Kjedahl nitrogen shows high yields of $94 \%$ to $97 \%$ for the different beds. All three pilots have insured generally good nitrogen mineralization while the plants are still young.

However, given the results obtained with the filtrates for the various beds with high values of certain parameters such as conductivity, $\mathrm{BOD}_{5}$, orthophosphates, nitrates..., they can not be released directly into the wild. They require additional treatment by co-treatment like in sewage lagoons. Nevertheless, we believe that the pilots performances can be improved over a long period of operation, with the development of the root system of plants.

\section{References}

[1] Mbéguéré, M., Dodane, P.-H. and Koné, D. (2009) Gestion des boues de vidange:optimisation de la filière EAWAG. $65 \mathrm{p}$.

[2] Montagnero, A. and Strauss, M. (2002) Gestion des boues de vidange. Institut de Recherche sur l'Eau du Domaine des écoles polytechniques fédérales (EAWAG) département Eau et Assainissement dans les pays en développement (SANDEC). 63 p.

[3] Strauss, M., Koné, D., Koanda, H. and Steiner, M. (2006) Gestion des Matières Fécales Urbaines - Situation, Défis et Solutions Prometteuses Elaboré par Eawag - Sandec. $1^{\text {er }}$ Symposium/Atelier International sur la Politique de Gestion des Boues de Vidange (GBV). 16 p.

[4] Koné, M. (2011) Infiltration-percolation sur sable et sur fibre de coco; filtre plantés et épuration d'eaux usées domestiques à dominance agroalimentaire sous climat tropical, sec; cas des eaux résiduaires urbaines de Ouagadougou. Thèse de Doctorat: Spécialité: Ingénierie de l’Eau et de l’Environnement. Université Claude Bernard Lyon1. 224 p.

[5] Langergraber, G. (2013) Are Constructed Treatment Wetlands Sustainable Sanitation Solutions? Water Science \& Technology, 67, 2133-2140. http://dx.doi.org/10.2166/wst.2013.122

[6] Koné, M., Zongo, I. and Bonou, L. (2011) Traitement d’eaux résiduaires urbaines par filtres plantés à flux vertical sous climat Soudano-Sahélien. International Journal of Biological and Chemical Sciences, 5, 217-231. http://dx.doi.org/10.4314/ijbcs.v5i1.68100

[7] Allandiguibaye, V. (2003) Etat des lieux de la gestion des boues de vidange dans la ville de Ouahigouya, mémoire pour de Master II. Option: Eau et Assainissement 2iE. 65 p.

[8] Barro, R. (2011) Contribution à la mise en place d'une station de traitement des matières de vidange par lits de séchage plantés de Echinochloa pyramidalis à Ouagadougou; mémoire de Master II en Eau et Assainissement 2iE, 63p.

[9] Abiola, T.F.S., Mbéguéré, M., Dodane, P.H. and Koné, D. (2009) Traitement des boues de vidange domestiques à Dakar (Sénégal): Etude du comportement et des performances d'une plante fourragère Echinochloa pyramidalis dans les lits de séchage en grandeur réelle. Gestion des Boues de Vidange optimisation de la filière. SANDEC EAWAG. 57-60.

[10] Lienard, A. (2004) Traitement des matières de vidange en milieu rural: Evaluation écotechnique des filières, document technique FNDAE n³0 CEMAGREF Editions; 91p (réf du 28 janvier 2009) disponible sur internet: http://www.fndae.fr

[11] Kengne, N.I.M. (2009) Potentials of Sludge Drying Beds Vegetated with Cyperus papyrus L. and Echinochloa pyramidalis (Lam.) Hitchc. \& Chase for Faecal Sludge Treatment in Tropical Regions, thèse de PHD/Doctorat spécialité: Phytoremediation. 114 p. 